\title{
Tikkun Beyond Borders: An Introduction
}

YVETTE DANIEL

\begin{abstract}
"We are an adaptable species and this adaptability has enabled us to survive. However, adaptability can also constitute a threat; we may become habituated to certain dangers and fail to recognize them until it's too late" (Hitchens, 2001, p. 51).
\end{abstract}

One of our youth researchers observed that while he had been actively engaging in civic life through volunteering in local organizations, he encountered many obstacles. He stated that the various organizations (with all good intent) where he volunteered were basically carrying out the status quo. Mostly, they wanted him to comply. This observation exemplified several comments in the same vein that permeated our formal and informal discussions with young people engaged in civic life in their local communities. However, the young people in our project at the various sites refused to become "habituated/complacent" with current conditions. They questioned the "familiar" in their communities with the hope for healing and reconciliation in their community engagement and action for social justice. As such, they attempted to dislodge representations that failed to capture youth power and potential to show spaces where youth could play important roles as organizers and leaders.

When Pope Francis visited Myanmar on November 28, 2017, he stated that reconciliation began with a respect for human rights. In a video message sent to Myanmar prior to his visit, the Pope said he aimed to spread the message of "reconciliation, forgiveness, and peace" (Vatican News, 2017). Repair, healing, and reconciliation as the path to social justice are the key concepts that forged our Tikkun Youth Project and the culminating Tikkun Youth Symposium that I introduce in this opening introductory chapter. It serves as a gateway to the variety of interesting and engaging chapters that are eclectic in style and substance to illuminate the different activities of this project. 


\section{The Meaning of Tikkun in an Inclusive Broad Sense of Social Justice ${ }^{\mathrm{I}}$}

We apply the concept of Tikkun to the non-sectarian aim of working for social justice through human action for healing, repair, and reconciliation. The concept of Tikkun has wider social non-denominational appeal and indicates actions directed at repairing the harm/injustices in this world. Sacks (2005) was instrumental in promoting the concept of Tikkun Olam as a liberal movement for social justice causes. In the original text, the precise term is Tikkun HaOlam which means "repairing the world" using the definite article "ha" (Rosenthal, 2005). The source of this concept is in important Jewish religious texts such as the Talmud, Midrash, and Mishnah, and in prayers where this term/phrase appears numerous times (Rosenthal, 2005). In its earlier usage, the term denoted legal application for repairing harm. With the advent of Jewish mysticism, however, the meaning and use of this term shifted from legal/judicial processes (outlined by sages and judges) to cosmic importance and to the role of human deeds in repairing "the flaws in the universe" (Rosenthal, 2005, p. 225).

For the purpose of our partnership development project, we underscored the philosophical principles of repair and healing that were relevant to the contexts of the different partnering sites. Through initial sharing of ideas and issues among partners, we found ways to coalesce around these principles that served as the inspiration for all researchers, youth activists, and community organizations. Despite the geo-political, cultural, historical, economic, and social differences among participants at these far-flung sites in our partnership, we were able to collaborate through the Tikkun framework that resonated with youth researchers, university researchers, and community organizations. In coming together and sharing their experiences, they found some common issues and the most significant one being that youth wanted to be taken seriously so their voices were heard in their work for healing, repair, and social justice. Our research and partnership supported the development of the next generation of socially responsible leaders who attempted to understand the practices of active citizenship by exploring similarities and differences of access to justice and fairness across different jurisdictions. They engaged in dialogue and 
participatory action research and initiated and/or sustained innovative programs and practices.

\section{The Tikkun Youth Project: Background Information}

Pedagogies of Repair and Reconciliation (Tikkun): The Embodied Praxis of Youth Civic Engagement is the official title of this project and partnership; henceforth, in the book it is referred to as the Tikkun Youth Project. The Tikkun Youth Project evolved from its inception as a three-year Social Sciences and Humanities Research Council (SSHRC) and University of Windsor funded partnership research grant awarded in 2014. The five sites of this partnership project came together organically out of previous attempts to seek funding for our work with youth. Since the process of working to put together a proposal for this prestigious grant took some time, patience, and persistence, in the interim we were able to consolidate ideas and build bridges among youth researchers, community organizations, and university researchers at the different sites. An ethic of responsibility and praxis (informed committed action) to others served as the foundation for this youth-focused partnership between the University of Windsor and our Canadian and international sites. Each one of us, in our humanity, is bound to others through an ethic of responsibility to take action(s) in order to repair the fractures (injustices and indignities) and transform the world through healing and reconciliation. The Truth and Reconciliation Commission of Canada (2015) report was a testament and also a stark reminder of the work of healing and repair still needed in Canada in order to address the legacy of trauma inflicted upon generations of Aboriginal peoples (First Nation, Metis, and Inuit-FNMI) through the residential school system and other gross injustices inflicted upon them since first contact. In post-apartheid South Africa, a TRC was set up to address injustices of the apartheid era. In general, there is little faith in the efficacy of these reports, but the establishment of these commissions underscored the need for healing and reconciliation as societies move forward in hope for a better environment for people who had suffered (and still suffer) injustices. In post-war Kosovo (part of the war in the Balkans after the collapse of Yugoslavia), no such TRC was established 
to address the injustices perpetrated during the years of conflict. It should be noted, however, that official government documents, under the influence of the European Union, place great emphasis on the role of youth in nationbuilding. Youth advocates, in general, have the potential to take on this moral and ethical responsibility for a better world. Therefore, the guiding principles of the project are: Tikkun (healing, repair, and reconciliation), youth leadership for advocacy and change, and embodied praxis (i.e., youth engaging in mindful and thoughtful social action through a lived sense of self and a focus on the lived experiences). For the project, active youth civic engagement was manifested at three levels: active citizenship that is personally responsible; participatory; and socially just and transformative (Westheimer \& Kahne, 2004).

This Tikkun Youth Project created a partnership to reach out to marginalized youth from five communities that collaborated for youth advocacy and engagement. These particular communities in need of healing, change, and reconciliation were located in South Africa, Kosovo, and Canada. Despite the end of apartheid in South Africa, inequities are rampant and impact youth the most (Swartz, Hamilton Harding, \& De Lannoy, 2012). Since the end of the Kosovo War, there has been an urgent need to repair relationships and establish trust among Serbian, Albanian, Kosovar, and Bosnian youth. In Canada, Indigenous (FNMI) and immigrant youth are disproportionately dropping out, or being pushed out, of secondary schools and are at higher risk for police apprehension or incarceration (Korteweg, 2010; Reading \& Wien, 2009). These dynamics of social exclusion are equally glaring in urban and rural communities across Ontario (Canada), South Africa, and Kosovo. At the same time, youth (ages 10-25) have become the world's largest demographic group (United Nations, 2013). By virtue of their numbers alone, young people have the potential to effect positive social change if provided opportunities for meaningful participation and leadership in civic life.

When we examine the manner in which youth are defining citizenship and civic engagement, there has been a noted shift away from interacting with the "traditional" forms of engagement, such as with the state. Instead, youth are gravitating towards actions and utilizing skills, such as network building, that are motivated by pertinent local issues of glaring injustices. With these techniques and goals, youth are able to utilize experiences from everyday life as a catalyst for participating and creating change in their locales (Harris \& Roose, 2014). When we look at understanding what citizenship means, 
we draw upon O'Loughlin (2006) who described citizenship as communitybased, drawing on the aspects of coming together as a community and the feelings we share with each other. Citizenship highlights the idea of a "shared embodiment" (O'Loughlin, 2006, p. 86) that creates solidarity amongst individuals. Smith, Lister, Middleton, and Cox (2005) identify citizenship as being the relationship that individuals have with their wider society. Furthermore, citizenship revolves around the feelings that individuals have about their role and position within that society.

Marginalized youth disproportionately experience social and economic exclusion due to systemic, legal, and social barriers. Our project sought to address these inequities by fostering collaboration across borders and by explicitly increasing the capacity of marginalized youth in diverse contexts to challenge inequities through local projects that advocate for healing and change. In line with Quintelier (2008), we argued that it was imperative to gain an understanding of the processes that lead youth to become engaged in civic life, especially those who had been marginalized through intergenerational impacts of social injustices. Research of programs that focused on encouraging and developing connected citizens had shown that young people were prepared and eager to contribute their talent and to improve their communities (Nicholson, Collins, \& Holmer, 2004).

Studies of such programs suggest that "[r]ather than 'leading,' adults need to be in the background, monitoring, mentoring, facilitating, but not being in charge" (Watts \& Flanagan, 2007, p. 782). Camino and Zeldin (2002) observed that youth seek adult support in the form of coaching, dialogue, and facilitating connections to sources of institutional, community, and political power. In this partnership, adult support at each site was demonstrated in training youth in conducting research for social action. Youth initiatives for advocacy at the local level were guided by the grassroots stages of initiation where youth collaborated to interrogate current action projects and/or create new ones; legitimation where they had local community support for their initiatives; implementation where they carry out their proposed plan of action; and lastly, the evaluative reflective stage (Willie, 2009 as referenced in Angara, 2011).

Through our project, we developed this cross-border partnership for youth-led embodied praxis in social justice across borders. The specific objectives of our partnership were as follows: 1) identify the places and resources to engage marginalized youth in youth-led advocacy for positive civic change; 2) explore the ways that these new understandings are 
translated into the youth's embodied experiences of civic engagement; 3 ) generate data to inform the development and mobilization of educational models to repair injustices through youth civic engagement; and 4) consolidate and expand our partnership to formal and informal educational institutions. In order to achieve these objectives, we first researched the manner in which citizenship and civic engagement were practiced in the lived reality of youth at these different sites and to consider the lessons they could learn from each other. We wanted to understand the perspectives of youth and the roles they played in civic engagement in repairing and healing based on an ethic of collective responsibility. Lastly, through our project and partnership, we highlighted the extent to which participatory action research serves to accelerate youth civic engagement. Without a strong partnership that combines considerable academic research experience (through the involvement of five universities), community-related advocacy experience, and the building of partnerships among these various entities, it would not be possible to work towards the goals of this project.

\section{Project Partners: An Overview}

Each site was affiliated with one local university headed by one or more university researchers, along with one non-profit organization engaged with youth engagement. I was the Principal Investigator for this SSHRC/ University of Windsor funded project and our university served as the project hub. In Ontario, we partnered with two sites - York University and the Canadian Civil Liberties Education Trust (CCLET) in Toronto; and Lakehead University and the Nishnawbe Aski-Nation (NAN) in Thunder Bay. Internationally, we had two partners: the University of Prishtina and International Progressive Education (IPE) that facilitated youth advocacy in Prishtina; and Kosovo (note that the chapter by Selimos et al. provides further details about Kosovo) and the University of Cape Town and Equal Education (EE) where youth (called Equalizers) advocate for equality in education in the post-apartheid era, and especially in Khayelitsha, a township located on the outskirts of Cape Town.

International Progressive Education (IPE) and Kosovar youth advocates. Since the end of the War in 1999, Kosovo, one of the successor states of the former Yugoslavia (Krasniqi, 2010), continues to exist in a post-war 
rebuilding phase. The main concerns among government officials, nongovernmental organizations (NGOs), the United Nations (UN), the European Union (EU), and others heavily involved in rebuilding Kosovo were the ideologies that are shaping this new nation state. Since Kosovo has a very young population along with a high unemployment rate, the need to involve youth is particularly pressing. A new citizenship education program was established in schools and many informal citizenship-learning opportunities/training programs were created by non-governmental organizations. In general, the vision of the new "Kosovar citizen" was a project of the EU, the UN, and the United States Agency for International Development (USAID), and hence, it had a strong European influence in all aspects, and especially in education. This image of the new citizen represented the dominant idea of citizenship in Kosovo. But the ideas often promoted in these settings contradicted other ways that different people envisioned this new nation and roles for citizenship.

International Progressive Education (IPE) $)^{2}$, our partnering organization, founded in 2010, was an educational non-profit organization in Prishtina, Kosovo. IPE was dedicated to expanding educational opportunities for Kosovar youth through educational research on important issues facing young Kosovars, as well as through innovative formal and non-formal educational projects (International Progressive Education, n.d.). IPE was also committed to promoting inter-ethnic reconciliation in the Balkan region. IPE became a country partner to the Global Youth Service Day (GYSD), the world's largest celebration of young volunteers. IPE worked to recruit and coordinate with local groups and organizations to participate in GYSD. Therefore, one of the first steps in this partnership with IPE and local youth was to understand how young people articulated and embodied the ideas for citizenship and advocacy in their daily lives. Through the Tikkun Youth Project in which participatory action research (PAR) served as the main investigative tool, we examined how citizenship was practiced and embodied by young people in Kosovo. Further, we gained insights into the role youth activism related initiatives play in healing the wounds of conflict and to further community relationship-building. Finally, based on the Tikkun concept of repair and reconciliation, our partnership highlighted youth potential in "bridging" the divide among the multiplicity of ethnicities in post-war Kosovo nation-building efforts.

Equal Education (EE) and Equalizers. Equal Education (EE) is a non-profit community organization located in the township of Khayelitsha, South 
Africa. Since its inception in 2008, EE has focused on developing the political and social consciousness and the leadership abilities of youth through formal and informal training programs ("Our Movement," n.d.). EE organizes and facilitates regular youth group sessions where issues related to education in South Africa and other local and international issues concerning youth development are explored. EE utilizes evidence-based activism to improve the school system, especially schools in crisis in South Africa ("Our Movement," n.d.). EE youth leaders called "Equalizers" are involved in many projects, such as assisting a high school in Khayelitsha to fix its leaking roof as well as an amazing campaign to fix 500 broken windows at Luhlaza Secondary School (Angara, 2011). Further, EE also employs legal means when they seek to address glaring injustices. For instance, EE sought a court order to force the Education Minister to meet promises made to set a national standard requirement for school facilities ("Equal Education," 2012).

Nishnawbe Aski Nation (NAN) and Youth Amplifiers. Nishnawbe Aski Nation (NAN) is a political territorial organization that represents 49 First Nations in the province of Ontario, with a population of 45,000. NAN encompasses James Bay Treaty No. 9 and Ontario's portion of Treaty No. 5. At this site, an indigenized approach for Indigenous - Youth Participatory Action Research (I-YPAR) incorporated the four "Rs" of Indigenous education that emphasizes 1) repair of the trauma and traumatic effects of schooling from the legacies of the Indian Residential School system and ongoing colonization; 2) respect for Indigenous youth to self-determine and define their needs for improvement of life and social/societal conditions; 3) regeneration/revitalization of hope, strength, and resilience for youth in order to bring forth 4) reclamation/resurgence by youth of their culture, communities, languages, and Land practices for greater civic/democratic engagement (Grande, 2004; Kirkness \& Barnhardt, 1991).

Canadian Civil Liberties Education Trust (CCLET) and Urban Youth Advocates in Toronto. CCLET is a branch of the Canadian Civil Liberties Association (CCLA) in Toronto. CCLET's educational programs offer in-class workshops, interactive seminars, and lectures on Canadian rights and freedoms for youth (Canadian Civil Liberties Association, n.d.). Participants learn that democracy requires them to make choices, and these choices are not only between good and bad, but more likely to be between the lesser of two or more evils. Students are engaged in thinking critically about the conflicts of rights that all people living in democracies face.

CCLET contributed its expertise in the design, development, and 
implementation of youth-targeted activities for the partnership. CCLET participated in project-related activities at the Toronto site, provided a support network at the local level, assisted in recruiting youth through their connections with various local organizations, and assisted in knowledge mobilization through their association with various organizations at the local, provincial, and national levels to develop democratic habits, such as critical thinking and active citizenship engagement.

Multicultural Council of Windsor and Essex County (MCC). Multicultural Council of Windsor and Essex County (MCC) is a non-profit organization that provides community-based services to urban and rural communities in the region (Multicultural Council of Windsor and Essex County, n.d.). In particular, they are dedicated to providing resources for newcomers (immigrants and refugees) to Canada with a focus on settlement and integration. MCC is, in fact, an umbrella organization of community-based organizations with expertise in promoting cultural sensitivity, anti-racism education, newcomer integration, and intercultural relations within the community and beyond (Multicultural Council of Windsor and Essex County, n.d.). Through their various youth organizations, MCC plays an active role in facilitating access to youth participants and also in facilitating, planning, and implementing knowledge mobilization activities. MCC benefits from the partnership by being able to facilitate small and large-scale adaptation of intervention/pilot programs and modules. Some of our youth researchers were already involved in initiatives supported by the MCC. For example, they initiated a local community garden cooperative in which residents collaborated to grow and share fresh produce. They also worked with new immigrants to help them in the various phases of their settlement, especially supporting young girls and women in accessing services. Further, they participated in anti-poverty initiatives and programs geared to promoting minority rights and gender equality.

\section{Challenges in Building a Partnership}

All community organizations involved in our project were non-profit, and working on tight budgets and with personnel who were already stretched to the limit with their workload.

The geographic distance and time zone differences among and between 
the different sites made collaboration and communication difficult to coordinate. The hub site in Windsor played a key role in ensuring that these challenges were met through the use of information communication technologies to record, relay, and coordinate activities. Furthermore, our youth researchers led hectic lives with other commitments such as school, work, and family obligations that made scheduling meetings and training sessions rather a daunting task. An additional challenge was that many of our youth participants had little experience with participatory action research (PAR) where they were active participants conducting interviews and other such research related responsibilities; hence, training was required before they went out to interview their recruited participants. Also, we had to account for different cultural and social expectations for each site, such as pace of work, meeting deadlines, making assumptions based on our values of time and efficiency, and such other issues. John Antoniw's chapter featured in this book is based on an autoethnographic approach; he expands on the challenges and the ways we had to overcome them.

\section{Methodological Processes}

We employed participatory action research (PAR) in which youth participants were also researchers. At each site, our youth researchers were trained to become active researchers. PAR is also effective in developing youth leadership skills (Rodrigues \& Brown, 2009). PAR interrogates the role of power and existing forms of knowledge construction in order to enable youth to construct knowledge for action guided by the principles of fairness, equity, and social justice.

We adopted a three-stage methodological process for this project. In the first stage, we solidified the partnership by setting up the project at the five different sites with Windsor being the hub site. The teams at the sites included university researchers, members of the partnering community organizations, and youth researchers/participants. We held regular meetings via Skype, and through emails and other forms of information and communications technology (ICT), we prioritized our objectives and established rapport and trust. Since we worked with sites and youth that did not have consistent access to ICTs, each organization provided the equipment, software, and training. 
In the second stage, we recruited and trained youth researchers by the university (each partnering organization is linked to at least one university researcher) as participant-researchers to conduct interviews with peers (3-4 interviews each). These interviews focused on understanding what youth knew about civic engagement and access to justice/social justice and the manner in which these understandings were shaped by their school/ curriculum, especially with regards to civic education and media literacy, family, culture, and social context. Further, these interviews were designed to understand the extent to which youth engaged in critical thinking question the structures that shaped their lived realities. The resulting data were collated, analyzed, and shared among participants.

The highlight of the third and final stage of the project was the Tikkun Youth Symposium for which members from all our sites travelled to Windsor for four days in early April 2017. The symposium titled "Tikkun Beyond Borders: Connecting Youth Voices and Leading Change" was organized to celebrate the voices of youth engaged in healing and reconciliation (Tikkun) through social justice activities, and to network among participants from the five sites collaborating on the Tikkun Youth Project and other youth activists in Windsor and beyond. Youth researchers, academics, and community leaders were engaged in dialogue and discussion about issues facing young people around the world and discussed ways of leading change for equity and social justice.

The planning, organization, and execution of this symposium was made possible through the support and collaboration of all teams, and in particular the Windsor team that hosted the symposium. Despite virtual meetings over the past two years, the symposium provided a real opportunity to meet, connect, share resources, have fun, and discover the similarities and differences among the social issues and challenges youth leaders faced at each site. Symposium participants shared resources through formal and informal meetings to explore their effectiveness in building knowledge about the facilitation of active community and leadership among youth. Further, these activities raised consciousness about the challenges as well as the opportunities for addressing injustices at the individual and community levels. The Artnote was one of the important events held during the Tikkun Youth Symposium. During the numerous planning meetings, we discussed various ways in which we could highlight our research findings in ways that would be accessible to all and in particular to youth involved in civic life. We played around with different ideas and went through a list of different 
activities and potential keynote speakers for the final day. We recruited an award-winning local artist, Chris Rabideau, who created the Artnote and served as the artistic director. Further, we were also influenced by Prosser and Loxley's (2008) review paper on visual methods to represent data. Prosser and Loxley focused on photographs and videos as data sources. They claimed that until a few decades ago visual data methods were invisible and that visual methods promise "enhanced analytical insights of everyday social worlds" (p. 4). Although the aforementioned authors focused on images and videos as a method of data collection, we extended this concept to use the medium of drama, music, and dance to share our partnership findings among sites and with the local invitees; many were youth leaders, academics, and from other youth organizations. Bell's (2010) Storytelling Project Model also influenced our decision to create an inclusive Artnote not only as a way for our youth to disseminate their findings, but also as a tool for reflection and learning. We included our local youth in different ways as well. We invited Syrian youth drummers (recent arrivals to Canada) to open the formal part of the day with a drumming circle. After the Artnote, a group of recently arrived Syrian refugee youth put on an amazing and heartwrenching play about their experiences growing up under constant siege and then their journey to get to Canada. By the end of their short play, there wasn't a dry eye in the audience.

On the last day of the symposium, we held our final meeting for reflection, debriefing, and future directions for our youth. Having spent over three packed days together in intensive activities, our participants developed strong bonds and the common theme of "youth for social justice and change" continued to guide their discussions and reflections. They shared their hopes and ideas for civic-engagement activities/initiatives in their local contexts. Further, they stated that participating in the symposium was memorable and moving. One of our participants explained that in coming together for the symposium and through the different activities over the four days, they were able to understand the issues that were unique, but also that so many issues are common to youth regardless of where they lived. They suggested the idea of creating an e-book to document their experiences in this Tikkun Youth Project. Therefore, two years or so later here we are with a collection of engaging chapters written by our project participants and also local organizers who participated in the four day symposium. Below, I provide a glimpse of the chapters in this collection. We have a range 
of authors that include academic researchers, youth researchers, youth participants, symposium participants, and others.

\section{Introduction to the Chapters}

Erwin Dimitri Selimos, Ereblir Kadriu, and Janet Balyeat's contributions to the project at the Kosovo site are clearly delineated in their chapter with a balance between personal experiences and conceptual understanding of research and partnership-building. They provide a brief history of the conflict and the challenges faced by Kosovar youth in the post-war nationbuilding period. Youth researchers explained their involvement in creating a new and better future for themselves and others. This chapter discusses the unique issues faced by young people in Kosovo and the ways in which the Tikkun Youth Project has assisted them in taking on leadership roles. The authors also provide a succinct overview of the entire Tikkun Youth Project and the ways in which PAR methodology was deployed at this site.

In Chris Rabideau and Karen Roland's chapter "Artnote: Data as Performance," they take us on a journey through the process of creating the Artnote from its inception to its grand finale. They argue that this Artnote should not be seen only as a one-time performance but as a Storytelling Project Model and as a way of presenting data and findings in a unique way. They walk us through the challenges and successes of this approach and provide a comprehensive description of the Artnote created by our participants within three days of coming together in Windsor for the Tikkun Youth Symposium.

Danielle McLaughlin was an active partner in the project. During the Tikkun Youth Symposium, she had in-depth conversations with our youth from the different sites. This chapter evolved from her reflections on these conversations in which she first discusses the different ways in which youth face discrimination (e.g., "mosquito sounds" outside of certain businesses, curfews, reduced minimum wage for those under the age of majority, youth not being involved in making decisions that affect them, etc.). Next, she identifies specific issues that youth at each site encountered, such as the ethnic separation in Kosovo, the fight for a living wage in Windsor, the 
challenges of education for Indigenous youth in Thunder Bay, and the fight for a decent education in impoverished areas in Cape Town, South Africa.

Our team from South Africa (Siphenathi Fulani, Salma Ismail, Sisanda Khuzani, Lona Mtembu, Lyndal Pottier, Amanda Maxongo, Aphiwe Tomose, and Phelokazi Tsoko) collaborated to write an in-depth chapter guided by Salma Ismail and Lyndal Pottier. They focus on the youth researchers' understanding of the concept of Tikkun and connecting it to Ubuntu in their context of post-apartheid South Africa. They describe the challenges faced by young people in Khayelitsha and the work done by Equalizers through an organization called Equal Education to fight for rights to a quality education in impoverished areas. In their involvement with the Tikkun Youth Project, they faced challenges when employing the PAR method, such as time zone issues, weak Internet connection, minimal access to the ICT, and the cost of transportation. Through their research, they found that youth's motivation for activism ranged from growing up in poverty to growing up in a middle-class political family, from experiences in prison and at tertiary institutions to teachers acting as role models and the influence of peers in organisations such as Equal Education. Their activism was demonstrated in a variety of ways from welfare type (e.g., tutoring learners, providing workshops in career guidance, and social entrepreneurship) to more activist type (e.g., raising consciousness about identities, gender, and Black consciousness, and involvement in student movements).

Erin Rose's chapter is a description of her journey to becoming an activist. Erin was one of the youth researchers from our Windsor site. Even though she had always been driven to fight for injustice, she felt of a sense of isolation in these struggles. When she became active in the project and participated in a provincial rally in the Fight for $\$ 15$ and Fairness for the first time, she felt validated as a youth activist and found a community of likeminded people and also found her voice. In this chapter, she delineates the trajectory of her emotions and experiences when meeting youth activists from the other sites at the week-long youth symposium held in Windsor in April 2017. She realises that healing and repair work for social justice was the thread that bound youth from different parts of the world together.

Ainslee Winter, who is a certified art therapist, discusses the importance of using art as a research methodology and as a different way for collecting data. She emphasizes the healing aspects of art therapy for youth, especially for those who have experienced oppression, trauma, or upheaval in their lives. At the Tikkun Youth Symposium, she facilitated a prayer flag art 
therapy session for our participants. At this session, Ainslee underscored the importance of art as healing and reconciliation both at an individual and at a communal level. Our youth participants shared their hopes and dreams to address the social issues they faced at their sites.

Dr. Lisa Korteweg, Jacky Chan, and Kylee Johnstone share the successes and challenges of the Tikkun Indigenous Youth Project - the project's site in northern Ontario/Canada. Here, the project was shaped by a collaborative Indigenous youth leadership, community engagement, and well-being project. The purpose was to support Indigenous students who had to leave their northern home communities to pursue secondary schooling in Thunder Bay. These students often faced insurmountable challenges when moving to a city far away from their homes. Through collaborative research with high schools, youth role-models, and educators, the team at Lakehead University in Thunder Bay was able to provide the conditions whereby Indigenous youth gained opportunities to meet and create bonds with their Indigenous peers. They participated in culturally-focused activities, shared stories in holistic circles, and developed their leadership skills while engaging in well-being practices and self-determining needs and actions. This chapter explains the philosophy and purpose of the culminating Landbased well-being retreat, as well as the Land-based outdoor leadership camp processes, the Leaders-in-Training strengths-based activities, and the responses of the youth participants, all decided, led, and engaged in by Indigenous youth, for Indigenous youth, and with Indigenous youth.

In the chapter contribution from our Toronto site, Nombuso Dlamini, Cynthia Kwakyewah, and Shawnee Hardware report on findings from data collected with and by youth researchers in the Greater Toronto Area (GTA). In this chapter, the authors expand on the ongoing scholarly debate in finding a definition for the complex concept of civic engagement. What does it mean for youth to be civically engaged and what are the different levels of engagement? How do youth find their voices? Oftentimes, when they feel that they do not connect in traditional formats for civic engagement, they seek out alternative spaces - especially digital spaces to feel empowered and to make their voices heard.

Nesreen Elkord and Lina Chaker highlight the pressing issues of the integration of newcomers to Canada and that of young people in particular through the lens of a girl named Randa (pseudonym), a recently arrived refugee from Syria. Her story is shared within the framework of social, cultural, and historical contexts and in particular Canada's humanitarian 
role in refugee re-settlement. They describe the methodology of narrative inquiry and present a three-dimensional narrative design based on temporality, sociality, and place while problematizing issues of trustworthiness from a reader's perspective. Randa shares her experiences of going to high school in Canada, participating in the Tikkun play, logistical challenges of the play, healing and reconciliation achieved through drama and role-play, civic agency and engagement, and her performance at the symposium. The authors present their analysis on refugee youth's civic engagement and refugee youth's journey to healing and reconciliation on a personal, social, and academic level.

Riham Al-Saadi was affiliated with the MCC in Windsor and Essex County (one of our partnering organizations). In recent years, Windsor and Essex County has been active in the re-settlement of Syrian refugees; according to the statistics, over 1,600 refugees have called this area home (Immigration, Refugees and Citizenship Canada, 2017). Riham examines the phenomenon of resettlement through the lens of acculturation, facilitative factors, and impediments that manifest themselves as these refugees seek to adapt to life in Windsor/Canada while trying to maintain their cultural heritage. In this chapter, Riham focuses on the narratives of three Syrian refugee youth as she believes that engaging with youth serves as healing by drawing upon their experiences and ensuring their voices are heard.

Evelina Baczewska and Francis Cachon's chapter provides us with a detailed account of their focus on the struggle for economic justice through the Fight for $\$ 15$ and Fairness in Windsor, as part of the provincial struggle for this issue. They discuss the ways in which youth respond to the economic, social, and political conditions that shape their lives, and they explore the ways in which Tikkun (healing and repair) is exemplified in their actions. They contend that the Tikkun Youth Project supported youth as important and valued stakeholders and provided them with opportunities to take an active role. Further, they dispel the myth that youth are disinterested/apathetic toward civic engagement and political struggles; the reality is that they often are excluded from them - a theme echoed in several other chapters as well.

John Antoniw's chapter wraps up this collection and also serves as a reflective and honest epilogue for the project. He uses the metaphor of a patchwork quilt to represent the five sites of this project. Since he was involved with the project from its inception, he could retell and reflect on the challenges and the successes that have occurred over the course of 
three years in addition to reflecting upon his own participation. He assesses and reflects on the cultural, structural, technological, and interpersonal challenges we had to overcome in bringing this partnership project to fruition. Antoniw provides useful recommendations that should be considered carefully in undertaking a similar international collaborative partnership project.

\section{Conclusion}

The process of creating these chapters and putting them together as an anthology has been a collaborative effort from the start. After the project had been completed and participants had moved on, they still honored the commitment they made at the Tikkun Youth Symposium to bring you this collection of engaging and diverse chapters that celebrate the voices of youth, their optimism and advocacy for healing, repair and reconciliation to build a better future. Despite the numerous challenges they faced, youth participant-researchers, university researchers, and partnering organizations exhibited resilience and dedication to activism for change throughout the duration of this project and beyond.

While the following twelve chapters could be read as stand-alone chapters, we anticipate that these narratives weave together to present you with a rich tapestry of stories of youth courage and leadership that offers insights into youth-led praxis (informed committed action) for social justice. We hope these engaging and accessible chapters inspire youth to move forward one step at a time and build skills for civic engagement and advocacy through further dialogue and debate about common and distinct issues young people around the world face and to facilitate discussion and sharing about ways of leading change for equity and social justice.

\section{References}

Angara, H. (2011). The 500 windows campaign: A case study of a youth movement for educational resources in South Africa. Interactions: UCLA 
Journal of Education and Information Studies, 7(2), 1-26. Retrieved from https://escholarship.org/uc/item/7r8387bx\#author

Bell, L. A. (2010). Storytelling for social justice: Connecting narrative and the arts in antiracist teaching. New York: Routledge Taylor \& Francis Group.

Camino, L., \& Zeldin, S. (2002). From periphery to center: Pathways for youth civic engagement in the day-to-day life of communities. Applied Developmental Science, 6(4), 213-220. doi:10.1207/S1532480XADS0604 8

Canadian Civil Liberties Association. (n.d.). Education. Retrieved from https://ccla.org/education/

Daniel, Y., \& Antoniw, J. (2016). Introduction to youth-led civic engagement for Tikkun: A developing partnership across borders (Canada, South Africa and Kosovo). Citizenship Education Research Journal, 5(1), 3-13. Retrieved from https://ojs-o.library.ubc.ca/index.php/CERJ/article/view/13

Equal Education takes Angie Motshekga to court. (2012, March 7). Mail $\mathcal{E}$ Guardian. Retrieved from https://mg.co.za/article/2012-03-07-equaleducation-takes-infrastructure-fight-to-court

Grande, S. (2004). Red pedagogy: Native American social and political thought. Rowman \& Littlefield.

Harris, A. \& Roose, J. (2014). DIY citizenship amongst young Muslims: Experience of the 'ordinary'. Journal of Youth Studies, 17(6), 794-813. doi:10.1080/13676261.2013.844782

Hitchens, C. (2001). Letters to a young contrarian. Cambridge, MA, Basic Books.

Immigration, Refugees and Citizenship Canada. (2017, November 1). Retrieved from https://www.canada.ca/en/immigration-refugees-citizenship/ news/notices/supplementary-immigration-levels-2018.html

International Progressive Education. (n.d.) About [Facebook page]. Retrieved from

https://www.facebook.com/pg/ipeducation/ about/?ref=page internal

Kirkness, V. J., \& Barnhardt, R. (1991). First Nations and higher education: The four R's - Respect, relevance, reciprocity, responsibility. Journal of American Indian Education, 30(3), 1-15. Retrieved from http://web.b.ebscohost.com.ledproxy2.uwindsor.ca/ehost/detail/ detail?vid=1\&sid=

23f6bcd4-f5b2-4cf2-a3bc-d39bb6e1f12f\%40pdcv-sessmgr01\&bdata=JnNpdGU9ZWhvc3QtbG12ZQ\%3d\%3d\#AN=119119262 $\& \mathrm{db}=\mathrm{a} 9 \mathrm{~h}$

Korteweg, L. (2010). The Lakehead Public School Board's urban Aboriginal 
education project. Retrieved from http://ontariodirectors.ca/ UA_Pilot_Project/files/Lakehead\%20RE/

UAEP_FINAL_REPORT_Review\%20and\%20Research\%20Study_LK_July1 6.pdf

Krasniqi, G. (2010). Citizenship as a tool of state-building in Kosovo: Status, rights, and identity in the new state. (CITSEE Working Paper Series; Vol. 2010, No. 10). CITSEE.

Multicultural Council of Windsor and Essex County. (n.d.). Retrieved from http://themcc.com/

Nicholson, H. J., Collins, C., \& Holmer, H. (2004). Youth as people: The protective aspects of youth development in after-school settings. The ANNALS of the American Academy of Political and Social Science, 591(1), 55-71. doi:10.1177/0002716203260081

O'Loughlin, M. (2006). Embodiment and education: Exploring creatural existence. Dordrecht, The Netherlands: Springer.

Our Movement. (n.d.). Retrieved from https://equaleducation.org.za/ourmovement/

Prosser, J., \& Loxley, A. (2008). Introducing visual methods. Discussion Paper. National Centre for Research Methods. (Unpublished). Retrieved from http://eprints.ncrm.ac.uk/420/

Quintelier, E. (2008). Who is politically active: The athlete, the scout member, or the environmental activist? Young people, voluntary engagement and political participation. Acta Sociological, 51(4), 355-370. doi:10.1177/ $\underline{0001699308097378}$

Reading, C. L., \& Wien, F. (2009). Health inequalities and social determinants of Aboriginal peoples' health. Prince George, BC: National Collaborating Centre for Aboriginal Health. Retrieved September 15, 2013 from https://www.ccnsa-nccah.ca/docs/determinants/ RPT-HealthInequalities-Reading-Wien-EN.pdf

Rodrigues, L., \& Brown, T. (2009). From voice to agency: Guiding principles for participatory action research with youth. New Directions for Youth Development, 123, 19-34. doi:10.1002/yd.312

Rosenthal, G. (2005). Tikkun ha-Olam: The metamorphosis of a concept. The Journal of Religion, 85(2), 214-240. doi:10.1086/427314

Sacks, J. (2005). To heal a fractured world: The ethics of responsibility. New York: Schocken Books.

Smith, N., Lister, R., Middleton, S., \& Cox, L. (2005). Young people as real 
citizens: Towards an inclusionary understanding of citizenship. Journal of Youth Studies, 8(4), 425-443. doi:10.1080/13676260500431743

Swartz, S., Hamilton Harding, J., \& De Lannoy, A. (2012). Ikasi style and the quiet violence of dreams: A critique of youth belonging in post-apartheid South Africa. Comparative Education, 48(1), 27-40. doi:10.1080/ $\underline{03050068.2011 .637761}$

Truth and Reconciliation Commission of Canada. (2015). Truth and reconciliation commission of Canada: Calls to action. Retrieved from https://nctr.ca/assets/reports/Calls to Action English2.pdf

United Nations (UN). (2013). International Conference on Population and Development: Beyond 2014. Thematic paper: Leadership and meaningful participation. Retrieved September 28, 2013 from http://icpdbeyond2014.org/uploads/browser/files/ leadership and_meaningful_participation.docx

Vatican News. (2017, November 22). Pope Francis sends video message to Myanmar ahead of visit. Vatican News. Retrieved from https://www.vaticannews.va/en/pope/news/2017-11/pope-francissends-video-message-to-myanmar-ahead-of-visit.html

Watts, R. J. \& Flanagan, C. (2007). Pushing the envelope on youth civic engagement: A developmental and liberation psychology perspective. Journal of Community Psychology, 35(6), 779-792. doi:10.1002/jcop.20178

Westheimer, J., \& Kahne, J. (2004). What kind of citizen? The politics of educating for democracy. American Educational Research Journal, 42(2), 237-269. doi:10.3102/00028312041002237

1 The description of the project, its methodology, and its partners are partly paraphrased from an article written during the first year of the project (Daniel \& Antoniw, 2016) and from the SSHRC partnership development grant proposal (SSHRC Grant \# 890-2013-0019) 2 International Progressive Education (IPE) is no longer an active organization. Its founders and youth participants have dispersed across the globe to continue their education, careers, and activism. 